\title{
WATER BALANCE IN NARSSAQ RIVER VALLEY
}

\author{
John Hansen and Bogdan Pulawski
}

As part of the UNESCO International Hydrological Decade Programme an account of the water balance in the Narssaq river region, South Greenland, was started in 1965. At the same time work is in progress to find out if the water supply is of the right quantity and quality to make possible extraction of the uranium-thorium ores at Kvanefjeld by flotation (see this report p. 49).

Narssaq river has its source in a local glacier without any connection to the inland ice, and runs into the fjord after about $12 \mathrm{~km}$. Two smaller tributaries drain two lakes, Kvanes $\varnothing$ and Taseq. The drainage area is about $30 \mathrm{~km}^{2}$. The area is mostly igneous rocks whilst the river valleys are mostly filled with weathered, fluviatile and glacial material.

The work comprises, 1) determination of the economy of the glacier, 2) determination of water flow in the rivers, 3) survey of the lakes, and 4) other determinations comprising precipitation, temperature, air humidity, visibility, wind strength and direction. At present the observations are only regularly undertaken during the summer; the rest of the year work is undertaken by a local man.

The glacier

The glacier consists of two tongues with a total area of ca. $2 \mathrm{~km}^{2}$. The highest point is $1200 \mathrm{~m}$ a.s.1. and the lowest $900 \mathrm{~m}$ a.s.1. The ablation and accumulation are measured with the help of stakes and totalisator gauges. So far measurements have only been undertaken in the ablation area at $1100 \mathrm{~m}$. From 20/6 - 26/8 $19652.5 \mathrm{~m}$ of snow melted off and the ice was left bare. When the 1966 season started $(25 / 6)$ a layer of only $1 \mathrm{~m}$ of snow covered the ice. From then until $1 / 91966$ the snow cover and $2.5 \mathrm{~m}$ of ice melted off.

Water flow in the rivers

The water flow is registered by 4 automatic gauges which operate for a week. The relation between the water level and flow is determined by radio isotopes ( $\mathrm{Ca}^{137}$ ) and a current meter (messflügel). The highest water flow measured in Narssaq river is $25 \mathrm{~m}^{3} / \mathrm{sec}$, the lowest $1.7 \mathrm{~m}^{3} / \mathrm{sec}$. From 
$20 / 6-26 / 81965$ the total melting and precipitation in the drainage area was ca. $20 \times 10^{6} \mathrm{~m}^{3}$ of water.

The lakes

The largest lake Taseq is $1.25 \mathrm{~km}^{2}$ with a maximum depth of $37 \mathrm{~m}$ and a volume of $18 \times 10^{6} \mathrm{~m}^{3}$ water. Kvanes $\phi$ is $0.25 \mathrm{~km}^{2}$ with a maximum depth of $5.5 \mathrm{~m}$ and a volume of $600 \times 10^{3} \mathrm{~m}^{3}$ water. The lakes are both situated ca. $500 \mathrm{~m}$ a.s.l.

Chemistry of the water

Resistivity, temperature and $\mathrm{pH}$ were measured along the rivers and in the lakes and many samples were collected for chemical analyses. Radioactivity was measured with a scintillation counter on 101 samples. Because of a high background the measurements were made on a boat in the middle of the fjord. The water has an extremely high content of fluorine which comes from dissolved villiaumite (NaF) in the lujavrutes and naujaites. The dry matter is less than $50 \mathrm{ppm}$ even in winter when there is a low water flow.

\section{Other measurements}

To get an understanding of the water balance the precipitation, temperature and air humidity are measured. The precipitation is determined by rain gauges and totalisator gauges placed at different places in the area. From $26 / 6$ - $12 / 91965 \mathrm{ca}$. $400 \mathrm{~mm}$ of rain was measured at sea level. In the same period during 1966 about double the amount was measured. The highest rain fall was in 1966; $105 \mathrm{~mm}$ in 20 hours. 